\title{
Volksraad (People Council): Radicale Concentratie Political Arena and National Fraction, 1918-1942
}

\author{
Nazirwan Rohmadi ${ }^{*}$; Warto ${ }^{2}$ \\ ${ }^{1}$ Graduate Student of History Education at Universitas Sebelas Maret, Indonesia; \\ ${ }^{2}$ Faculty of Cultural Sciences, Universitas Sebelas Maret, Indonesia \\ ${ }^{*}$ Corresponding Author: nazirwanr1899@gmail.com
}

\begin{abstract}
This paper discusses the legislative institutions called Volksraad established by the Dutch East Indies, which further used by the nationalist-moderate to achieve the national independence of Indonesia. Historical method was used in this research. The historical method is distinguished into several stages, namely heuristic, critic, analysis, and historiography. Indonesia's political figures established Radicale Concentratie to unite in order to achieve independence. Radicale Concentratie put a great pressure on the Dutch East Indies government. Radicale Concentratie no longer operated because of some conflicts that occurred among its members and the arrests done by the Dutch East Indies government. Radicale Concentratie's struggle was continued by National Fraction which was established on 27 January 1930. The proposition of National Fraction that was fulfilled was the change in the nomenclatur of Indlander to Indonesisch. National Fraction often turned down the budget plan proposed by the Governor-General in preparing for the Second World War. This is because the Dutch East Indies fleet was funded by Indonesian taxes and the taxes were planned to be increased in order to win the war.
\end{abstract}

Keywords: National Fraction; Radicale Concentratie; Volksraad

\section{INTRODUCTION}

Volksraad is a decentralization process of Dutch East Indies legal product. Volksraad was initially established on 18 May 1918. This legislative institution was the first representative institution of Indonesia. Mohammad Hatta and Haji Agus Salim claimed that Volksraad is a nonsense institution that did not serve any functions like any other real legislative institutions (Tempo, 2013: 45). The statement is related to Volksraad authority which served only as an institution counseling the Governor General.

Despite Volksraad was claimed as a nonsense, it had respected members which played a key role as the Indonesian people's spokesperson. Volksraad members who were seen as the fighters for people's aspirations then established a group called Radicale Concentratie.
Radicale Concentratie fought for expanding Volksraad authority to become a true legislative institution. To realize such mission, Radicale Concentratie proposed a motion known as the motion of H. O. S. Tjokroaminoto and Achmad Djajadiningrat. The motion was enacted by the Dutch parliament in 1925 by expanding Volksraad authority. The motion was successful in granting the authority in terms of budgeting, making laws, and monitoring government affairs. However, the authority to establish an investigation agency that would subjugate the Governor-General's power was not granted by the Dutch government.

Unfortunately, the approved motion failed to make Radicale Concentratie continue to grow. This is due to internal conflicts among Indonesian political parties in 
addition to the arrest of important figures in Radicale Concentratie, for example H. O. S. Tjokroaminoto. H. O. S. Tjokroaminoto was arrested on a charge of joining Afdeeling $B$ 's movement (Shiraishi, 1997: 316; and Ricklef, 2011: 271).

Radicale Concentratie's struggle was then continued by National Fraction-established on 27January 1930. The National Fraction was established since among the member shared similar interests. The objective of National Fraction was to help the Indonesian legally (Parliament) achieve the independence. National Fraction, which was the government's opposition, who used to speak out loudly in every debate with in the Volksraad. National Fraction's motion that was deemed successful was the motion to relabel the Indonesia's nomenclatur from Inlander into Indonesia. Nonetheless, there were more motions rejected by the government and made the members of National Fraction even turned into resentful. This eventually would engender the National Fraction to view the Japanese economic invasion as a hope for Indonesian people to declare their independence from the Dutch.

Based on the above, this paper focuses on the roles of Indonesian representatives in Volksraad, who fought under the name Radicale Concentratie and then National Fractie. In addition, this paper provides discussion on how the process of the Volksraad establishment from the Dutch and Indonesian viewpoints.

\section{THE ESTABLISHMENT OF THE VOLKSRAAD}

Volksraad was a legislative institution that took a long process of establishment. Its early establishment was begun by a proposal directed to the Governor General Van Twist to the Dutch Queen and parliament. The proposal advised the Dutch government to establish local councils in three major ports to promote efficiency and autonomy principles (Furnivall, 2009: 285). The proposal resulted a committee based on government decisions in 1866 and had several duties i.e. conducting an investigation related to the preparedness of indigenous Indonesian in running the government. The committee reported that the indigenous were still immature. They were not fully trusted to file a government agency represented only a minority of ruling races (Furnivall, 2009: 286).

Such investigation results led the Governor General Van Twist's proposal to be forgotten. Approximately 20 years later, Mr. Baron van Dedem, a colonization minister, once again brought up Van Twist's proposal. Mr. Baron van Dedem proposed that Raad van Nederland-Indie
(The Indies Council) be restructured. He proposed that Raad van Nederland-Indie be replaced by Een Koloniale Raad whose membership was more open, i.e. not only from the government officials (Wignjosoebroto, 2014: 122). However, his suggestion was not discussed for further (Poerbopranoto, 1938: 8; and Wignjosoebroto, 2014: 122). This was inseparable from the debate that occurred in the Dutch parliament related to the discussion of Decentralization Bill. Mr. Baron van Dedem then gave his thoughts on the Decentralization Bill. He proposed that the budget of the Dutch Indies be separated from the Dutch budget (Financial Decentralisatie), meaning that the Dutch East Indies government had to be independent and able to finance all the needs of the Dutch East Indies (Wignjosoebroto, 2014: 122; and Angelino, 1931). The discussion of Decentralization Bill ran slowly and it was difficult to reach an agreement due to the conservative group's objections and the executive officers' strong patronage since they kept wishing to be the rulers of the Dutch East Indies (Wignjosoebroto, 2014: 113).

Agreement on the Decentralization Bill was successfully made when A. W. F. Idenburg served as the colonial minister. The Decentralization Law was then enacted on 23 July 1903. In fact, the agreed decentralization law was not followed by the approval of Raad van Nederland-Indie changes. However, the thoughts of Mr. Baron van Dedem were then adopted by Minister Fock with the same goal of changing Raad van Nederland Indie (Furnivall, 2009: 290; and Wignjosoebroto, 2014: 122). In addition, Minister Fock insisted that the government implement the Decentralization Financials listed in 68a, $68 \mathrm{~b}$, and $68 \mathrm{c}$ of the Decentralization Law. Minister Fock proposed to the Dutch government that budgets (begrooting) of the Dutch East Indies be enacted by the Governor-General and Council (Poerbopranoto, 1938: 8). The proposal was later continued by Minister De Waal Malefijt in 1911.

Minister De Waal Malefijt stated that, because the Dutch-Indies had been established as a legal entity, Koloniale Raad should be immediately established and positioned as a representative institution (Wignjosoebroto, 2014: 122). He proposed that Koloniale Raad consist of 29 members, including the members of Raad van Indie; 11 members were elected by the local council members, representing the interests of the Europeans, and the remaining appointed members would represent the interests of the indigeneous (Furnivall, 2009: 290). However, a rapid change in the colonial minister had rendered the proposal discontinued because Minister De Waal Malefijt was succeeded by Minister Th. B. Pleyte. Minister Th. B. Pleyte adopted the basic ideas 
of some previous ministers related to representative institutions. He tried to invite the political parties whose promoters were the Indonesians such as Sarekat Islam and Budi Utomo. He did that so that all layers of the society in the Dutch East Indies could cooperate in the context of drafting the Dutch Indies budget and supporting the Dutch government in facing the First World War. In fact, Minister Th. B. Pleyte turned out to have different ideas related to this institution. He, instead, wanted the representative institution, that was to be established, to not replace Raad van Nederland-Indie (Wignjosoebroto, 2014: 123). But to stand side by side with Raad van Nederland-Indie. Minister Th. B. Pleyte also changed the nomenclature of Koloniale Raad to Volksraad which means People's Council. Volksraad served a similar function to that of Raad van Nederland-Indie as the advisory body to the Governor-General (Riphagen, 1927: 37).

The proposal of Minister Th. B. Pleyte was approved by Staaten Generaal and enacted on 16 December 1916 and came into force on 1 August 1917. Despite the fact that the parliament had approved the Minister Th. B. Pleyte's proposal, the public considered that Minister De Waal Malefijt the father of the People's Council. This is because Minister De Waal Malefijt would wish Koloniale Raad be established, and stand side by side with the Dutch Indies Council and have members elected by the people (Poerbopranoto, 1938: 8). The Volksraad establishment process in fact nuanced with differences among the Indonesian's perspective.

There known Indonesian political party Budi Utomo supported the government's decision to establish indigenous militias as a preparation to confront the First World War. The indigenous militia was established for it was believed to have been able to save the state budgets instead of enlarging the regular military forces (Ricklef, 2011: 261; and Pringgodigdo, 1986: 2-3). Budi Utomo extended its support through Indie Weerbaar (Indies Defense) campaigns to various regions. However, what Budi Utomo did reaped criticism from various political parties, one of which is Sarekat Islam. The Sarekat Islam, with H. O. S. Tjokroaminoto as its leader, believed that prior to conducting Indie Weerbaar, the Indonesian nation had to have representatives in the government. The government later responded to $\mathrm{H}$. O. S. Tjokroaminoto's suggestion by making concessions regarding volksvertegewordig (people's representatives) (Shiraishi, 1997: 102).

Later, Sarekat Islam received support from Budi Utomo. These two political parties then petitioned Queen Wilhelmina and traveled around the Dutch to conduct campaigns sustaining the establishment of military service for indigeneous Indonesian (Bumiputera militia) and representative institutions (Ricklef, 2011: 262). However, the bill for the formation of Bumiputera militia was rejected. The government only approved the establishment of a representative institution (Volksraad) which was later enacted on 16 December 1916. Volksraad was officially established on 18 May 1918 in Batavia (Simbolon, 2007: 296).

\section{VOLKSRAAD STRUCTURE}

Volksraad, which was officially established on 18 May 1918 marked by the speech of Governor General Van Limburg Stirum, joined by 38 members and a chairman. That number of members was based on the number of gewests in the Dutch Indies. The people who had the right to vote for Volksraad members were members of local raden. All the local raden (Kaboepaten Raad, Gemeenteraad, Gewestelijke Raad, and Afdeling Raad) in the Dutch East Indies were merged into kiezerscorps who voted for Volksraad members not based on nationality (Helsdingen, 1928: 35). The elected Volksraad members were entitled to a salary of $f 300$ with tenure of 3 years in 1918 (Angelino, 1931: 412). In addition, the composition of Volksraad members based on nationalities is as follows:

- 1 member who became Voorzitter (appointed by the Queen);

- 15 members of the Bumiputera nation (10 members were elected and 5 were appointed)

- 23 European and Foreign Oriental members (9 members were elected and 14 were appointed) (Helsdingen, 1928: 35).

The Indonesian nation, which was the majority nation in the Dutch East Indies, was represented only by a small number of people. However, the European people were the other way around, although they were minority in the Indies. Among the Indonesian representatives joining as the Volksraad members were those of the aristocrats (Adiputri, 2014: 2).

The policy led to a protest reaction against the government. The protests in Volksraad were mobilized by the members of Radicale Concentratie who demanded an increase in the number and authority of the Volksraad. The protest emerged from beyond the Volksraad, it was allegedly triggered by Mohammad Hatta's statement that noncooperation rejecting the schijn-parlement, false People's Council, created by the government to deceive people (Hatta, 2011: 51). Such statement referred to the number of Volksraad members that failed to represent the Indonesian nation.

The pressure then made the government file a 
decision to increase the number of Volksraad members in 1920. The government's reason was that the change was neccessary because there were many different kinds of political movements arose in the Dutch East Indies (Poerbopranoto, 1938: 11). The Volksraad after being changed constitute of the following members:

- 1 member who became Voorzitter (appointed by the Queen);

- 20 members of the Bumiputera nation (12 members elected and 8 appointed)

- 28 European and Foreigner Oriental members (12 selected and 16 appointed) (Poerbopranoto, 1938: 12).

Nevertheless, the change did not last long due to the change in Regeerings-Reglement into Indische Staatregeling in 1925 and the issue of Staatblad 1929 no.285. The change caused Volksraad to have 61 members. The members constitute the following criteria:

- 1 member who became Voorzitter (appointed by the Queen);

- 25 members of the Bumiputera nation (20 members elected and 5 appointed)

- 30 (minimum) Dutch members (15 elected and 15 appointed);

- 5 foreign members ( 3 elected and the remaining appointed) (Riphagen, 1927: 27; and Paulus, 1979: 23).

The Indische Staatregeling implementation did affect the Volksraad members voting procedure. The local raden based-nationality which is integrated under kiezerscorps was one of therequiring criteria inselecting their representatives (Riphagen 1927: 27). This means that Indonesian voters had to choose their representatives of the same nationality. Indonesian voters were not allowed to choose their representatives from Europeans or the Foreign Orientals. This also applied to voters from Europeans and the Foreign Orientals.

A number of the requirements to become a Volksraad member were a person who was at least 25 years old, a Dutchman, and a resident of the Dutch East Indies. A person who wished to become a Volksraad member could become a candidate only if he could obtain at least 5 signatures from the local raden members. The process began on October 14-15. The names of the persons that had been registered to be Volksraad members were then submitted to the local raden chairman and further submitted to the chairman of the electoral body (Stem Kantoor) in Batavia. The names of the candidates were then announced in the Javasche Courant (Poerbopranoto, 1938: 16-18).
According to Keizer (1939: 306-308), Volksraad used a stratified electoral system.

First, villagers select a keismannen. Second, keismannen select members of council at the regency level. Third, the members of the regency council select the people's council members through Gemeenteraad.

The elected Volksraad members were required to recite oath of allegiance to the Queen and were entitled to receive a salary of $f 2100$ each year.

Volksraad members only functioned as the advisory body of the Governor-General in 1918. However, the authority was expanded in 1927 because of that Volksraad was entitled to participate in drafting the Dutch Indies budget and making Law. Among the rights of Volksraad members are: being entitled to file a bill (Recht van Initiatief), being entitled to request information in a certain matter to the government (Recht van Interpelatie), and being entitled to file a motion to overthrow the position or government policy (Poerbopranoto, 1938: 23). Nevertheless, Volksraad was not given an authority to conduct an investigation. Such authority belonged to only the true Tweede Kamer and parliament.

Volksraad members who had broader rights and obligations were entitled to present their thoughts at the first meeting (15 June-15 September). The opinions brought up by Volksraad members used to be covering about budget planning, politics, and economy (Poerbopranoto, 1938: 21). The budget planning being discussed used to be in compliance with the departments established by the government, constitute of general government departments, warfare, and marine forces.

Volksraad conducted two ordinary sessions on 15 June-15 September and 10 January-20 February and an extraordinary session (Poerbopranoto, 1938: 29). Extraordinary session was held when the GovernorGeneral deemed it necessary to hold a forum and minimum 20 Volksraad members were required to attend and only attended by members residing on Java and Madura Island. Extraordinary sessions commonly discussed government's supplementary budgets or suggestions for the issuance of new laws.

Gedelegeerden Assembly had 15 members. They were Volksraad members who were elected by other Volksraad members. Four Volksraad members were entitled to select one member of Gedelegeerden Assembly (Riphagen, 1927: 28). The elected members were entitled to receive a salary of $f 700$. Gedelegeerden Assembly had the following duties: 
- To exercise some of the rights and authorities of People's Council given by Wet to them; the work was carried out by Gedelegeerden Assembly on behalf of the People's Council.

- To do all the inventory and preparation (voorbereidingsarbeid) for the work of the People's Council in terms of making state laws (Poerbopranoto, 1938: 36).

To carry out their duties, Gedelegeerden Assembly had the rights to make laws, draft laws, propose amendments, and revoke laws.

A law filed by the Governor-General would be discussed in the meetings conducted by Gedelegeerden Assembly. The decision obtained in Gedelegeerden Assembly meetings was then submitted to Volksraad leader to be further discussed in the general discussion. Volksraad's general discussion was attended by a department head. The decisions obtained in the Volksraad session were drawn from the votes of each member delivered orally (mondeling) (Poerbopranoto, 1938: 2324). Discussion of Law in Volksraad

"Usually the priority is on the things that can add a chance of winning to the party by impressing the electorates" (Helsdingen, 1928: 30).

If the Governor-General deemed it necessary to make a law, he would then enact the bill unilaterally. If that occured, Volksraad was entitled to request information from the Queen then the Queen could issue Algemeene maatregel van Bestuur (A. M. V. B). A. M. V. B had the function of giving a decision to a Bill that did not get an agreement between Volksraad and the Governor General (Poerbopranoto, 1938: 22).

\section{RADICALE CONCENTRATIE AND NATIONAL FRACTION}

Radicale Concentratie or Radical Concentration was a political wing in Volksraad that demanded a change in the structure of the Dutch East Indies government. This political wing was established based on the proposal of Ch. G. Cramer, a leader of ISDP party. This political wing was founded on 16 November 1918 (Soerjohardjo, 1976: 61). The political organizations integrated under Radicale Concentratie were Ch. G. Cramer (Indische Social Democratische Partij), Abdoel Rivai dan Tjipto Mangoenkoesoemo (Insulinde), H. O. S. Tjokroaminoto dan Abdoel Moeis (Central Sarekat Islam), Sastrowidjono (Boedi Oetomo), Haji Agus Salim (Sarekat Soematera), dan Darnakoesoema (Pasoendan).
Radical Concentration initiated by Ch. G. Cramer was led by H. O. S. Tjokroaminoto. It called for an extension of the rights and authority of Volksraad in order to become a true parliament. Knowing that a radical political wing had been established, the government sent Mr. Dr. D. Talma to deliver a government's promise. Mr. Dr. D. Talma asserted that any malicious regulations coming out of Volksraad sessions, would be revoked (Depdikbud, 1978: 120).

The government's promise was responded by Radical Concentration by filing a motion. The motion filed on 25 November 1918 was signed by H. O. S. Tjokroaminoto, Sastrowidjono, Dwidjesewojo, Cramer, Tjipto Mangoenkoesoemo, Radjiman, Teeuwen, Moeis and Thajeb. The contents of the motion are as follows:

As soon as possible, it should begin with the establishment of a parliament that is elected and composed by and from the people with full legal rights, and with the formation of a government that is responsible to the parliament (Wongsokoesoemo, 1940: 267-268).

The motion was then reinforced by a motion filed by Djajadiningrat on 3 December 1918 and signed by Schuman, Wawoeroentoe, van Hinloopen Labberton, Kan, and Jacob. The motion that also demanded zelfbestuur is as follows:

1. The establishment of a State Assembly (Rijksraad). In the assembly, it is mandated that each part of the Dutch Kingdom that has its own government be represented according to the rights and justice.

2. The change of the people's council into a representative body with the rights to make law, based on the principles of all members by election, and the increase in of the number of members.

3. The replacement of the current department heads with the state ministers responsible to the people's council, accompanied by a change in the division of work in the present department.

4. The change in the People's Council into Raad van State of the Indies should be carried out not by taking into account the differences of the nation.

5. The drafting of budget (begrooting) by the power of legal body in the Indies, and at the same time, the Governor-General's is granted rights to propose judicial appeal (recht van beroep) regarding all decisions taken by the representative institution before the state assembly (Rijksraad), and during waiting for the establishment of the assembly, it was in the presence of the power of legal body in the Dutch. 
6. Changes in the direction of the government towards decentralization that is continuous and gradual, first by setting up village assemblies and regenschap assemblies, and simultaneously establishing the same assemblies on the other lands (Wongsokoesoemo, 1940: 268).

The Government responded to the motion by establishing a reformation commission of Bills in the Dutch East Indies on 17 December 1918. However, the government later rejected the proposal of the commission which, instead, approved the motion filed by H. O. S. Tjokroaminoto and Djajadiningrat (Pringgodigdo, 1986: 46). Such political conditions, as well as an increase in investment that began coming in after the First World War, had made the Dutch East Indies warm. Indonesian politicians started to be aware that the capitalists only exploited Indonesian resources. This led Indonesian political actors to make a mass movement to oppose capitalism. It was led by Surjopranoto "King of Strike" from PFB and a member of Sarekat Islam (Budiawan, 2006). The movement conducted by Surjopranoto was opposed by some members of Radical Concentration. This then triggered a conflict in Radical Concentration. The condition was exacerbated by the arrest of H. O. S. Tjokroaminoto for allegedly participating in the Afdeeling $B$ rebellion (Shiraishi, 1997: 316; and Ricklef, 2011: 271). The last activity of this political wing was recorded on 13 February 1921 (Soerjohardjo, 1976: 85).

The Radical Concentration struggle was then continued by the second Radical Concentration which was established on 12 November 1922 (Pringgodigdo, 1986: 46). The second Radical Concentration had more coverage of members, because members of the Radical Concentratie first willing to rejoin and augmented by members from Semaun (Partai Komunis Indonesia), F. P. Dahler (Nationaal Indische Partij), A. J. Patty (Sarekat Ambon), and J. H. Pangemanan (Perserikatan Minahasa). Radicale Concentratie began using the word Indonesia to replace the colonial term "Indies" and start using the language of Indonesia (McVey, 2009: 197). These political wings moved outside and inside the People's Council wall to withstand against various government's oppressive policies to the Indonesian people. However, this political wing only lasted for approximately one year due to the presence of party discipline policy and a warm discussion about noncooperative attitude. This political wing then disappeared since the end of 1923.

Indonesian political condition that was in conflict exarcebated by the high taxes in the Dutch East Indies. The political condition and the high taxes in Nederland Indie triggered the emergence of rebellion by PKI against the government occurred in 1926-1927 in Banten and Silungkang, based on decision of the meeting at Prambanan (McVey, 2009).

Mohammad Husni Thamrin, a Volksraad member, had actually warned the government prior to the incident. He said that the government should not only worry about the rebellion, but they should also consider the causes of such movement. However, the government could end the rebellion by its military force.

Military forces continue to be used by the Dutch Indies with support article 151, 153, and 161. The article give the rights to the government to arrest to anyone who deliberately through the word, the writings, pictures, directly or indirectly, conditional and indirect ways, interfere with the security of public order or the overthrow of both suggested it in Nederland or Dutch East Indies guilty or therefore punished as high as six years or a fine as high as three hundred gulden (Handelingen, 1930: 1994).

The Article used by the government to arrest sukarno with accusations will make a resistance in 1930 (Handelingen, 1933: 346). This accusation is supported with delivering a speech criticism expressed related to the condition of the Dutch Indies (Handelingen, 1933: 347).

The Dutch East Indies government continued arresting without evidence and this caused the political party condition to be in paralysis. It was then responded by Indonesian representatives in Volksraad by forming a political wing of National Fractionon 27 January 1930. Some of the members of National Fraction were M. H. Thamrin (Betawi), Iskandardinata (Pasoendan), Soeroso (PVPN), Koesoemo Oetojo, Dwidjosewojo, Soekardjo Wirjopranoto, Wiwoho Poerbohadidjojo (BO), Mochtar bin Praboe Mangkoe Negara (Sumatera), Abdul Firman Gelar Maharadja Soangkoepon (Batak), and Jahja Datoek Kajo (Sumatera). National Fraction had a clear objective that is to achieve Indonesia Merdeka through a legitimate (Parliament) way (Suhatno, 1995: 131). The established National Faction challenged the government to open up evidence of arrests that had been carried out in front of the public, so that the world would know about it (Handelingen, 1938: 637). However, the government always rejected it and the arrested political leaders were only given space to defend in the trials. The defense was hopeless as they would end up in detention.

The National Faction attempt failed because the government played hard-to-get. This was influenced by the economic situation of the Dutch East Indies which was experiencing the peak of the world economic crisis in 1930. The crisis in the Indies was caused by an excessive production of goods since 1920 (Hatta, 1934: 
74-75). The signs of the economic crisis had started to emerge since 1920, but the capitalists did not care about it but only profit. The world crisis brought an opportunity for Japanese products to invadethe Dutch East Indies (Thamrin, 1934: 14). People at that time were very familiar with Japanese products because they were cheap and affordable. Even they all recognized a term " $D$ (jendral) J(apan) I(ni) $N$ (anti) T(oeloeng A(nak) N(egri)" (Thamrin, 1934: 14).

The government that successfully won the heart of Indonesians through the economic invasion had allocated its spies in Indonesia. Among the Japanese spies were in disguised as journalists and traders (Wanhar, 2014). The ability of Japan to do the economic invasion and spread many spies in Indonesia was inseparable from from its financial ability to produce goods at low prices. A different production cost between Japan and Europe could be seen from the cost of workers' salaries. Japanese workers were only paid $£ 0.6$ a day, while European workers were paid $£ 5$ day (Hatta, 2015: 103).

It brought the Dutch Indies government to conduct an economic war against Japan. That is why, the government was harsh to those who were labeled as someone who spread incitement and charge taxes to Indonesians (Handelingen, 1940: 782). Indonesian people never even experienced any economic development from the hard work that they did. This is because the economic results of the Dutch East Indies were used by the Dutch government. The circumstance then made Soetardjo Kartohadikoesoemo file apetition. The contents of the petition are as follows:

"...in order to establish aconferentieconsisting of delegates from the Dutch and Indonesia with a similar principle. Conferentiewill make a plan to create zelfstandigheid (stand alone)...."(A. M., 1938: 5).

Soetardjo Kartohadikoesoemo wanted a dominion status for Indonesia. Such petition was actually not totally new since it was almost identical to the motion of Djajadiningrat filed in 1918. The similarity lies in the desire of Soetardjo Kartohadikoesoemo to establish Rijksraad which served as a judge for any inter-state disputes within the Dutch kingdom. He also wanted the Governor General to be directly responsible to the People's Council. The petition was also supported by IEV (Indo-Europees Verbond). The IEV, supported the petition in Volksraad which, taking the American example in the Philippines as its model, called for more autonomy in a future Dutch-Indonesian union (Houben, 2013: 235).

Soetardjo Kartohadikoesoemo explained that the petition he filed on Thursday, 9 July 1936 was a form of disappointment that arose due to the "absence of the work of Indonesian Volksraad members." (Salim, 1936: 5) His statement was supported by one member of National Fraction named I. J. Kasimo. He stated that

"... when the Dutch do a something for the Indies, it contains a necessity of the Dutch; but when the Indies do something for the necessities of the Dutch, what the Indies do to the Dutch industry is of no use to the Indies; even often, it brings disadvantage especially the loss of the poor people due to price increases or so on.... " (Salim, 1936: 25).

The economic opression committed by the government against the indigenous Indonesian became the main reason to file the petition. The petition was then supported by 26 votes and rejected by 20 votes (Salim, 1936: 180). The approved petition was then submitted to the Dutch. However, it was rejected by Tweede Kamer in 1938 on the reason that the petition contents were unclear and manipulative.

The rejection was also based upon the explanations of the Governor General to the Staaten Generaal. The governor general explained to Minister of Colonies Charles Welter, the Indies had not yet reached an appropriate stage of political development, so the granting of 'dominion status', as requested by the crafters of the petition, was simply impossible. According to his assessment, the Dutch should proceed with those reforms already under way in the Indies: the colonial administration should work towards enhanced regional and local authority, while encouraging the 'Indies community' to take full advantage of their participatory powers in the form of the Volksraad (Foray, 2013: 8).

The rejection was actually inseparable from the European situation at that time. In 1938, the Dutch was under a war threat from Germany. However, the rejection had made the Indonesians disappointed and thought that Volksraad was indeed a nonsense institution. On the other hand, "the representatives become irritated and very angry or really hurt because their petitions do not get a proper attention" (Soetomo, 1937: 52).

The Indonesian representatives were even more hurt when the Dutch East Indies government drafted a Budget Plan to strengthen its fleet. The Dutch government did that to protect the Dutch East Indies from the Japanese threat. Such budget draft was submitted on 29 March 1940 with a total of $f 283,000,000$ (Soedirman, 1940: 141). The draft was approved by 38 votes and refused by 0 , while National Fraction did not cast their votes. 
National Fraction did not believe that such budget would be borne by the Dutch government to protect its colonies. Soekardjo Wirjopranoto delivered a speech at Volksraad as the following quote "The longer it is, we still shall have to borne the amount of the ships'procurement" (Soedirman, 1940: 144).

Soekardjo Wirjopranoto also reviewed the government's injustice in terms of providing an opportunity for the Indonesians to become a part of its navy. He said that "They work by using various tools to clean the ships." (Soedirman, 1940: 145) The Indonesians were treated as cleaning service workers in the warship.

Warships that were only driven by the Europeans would not be optimally functioning. National Fraction, represented by its leader Mohammad Husni Thamrin, said that

"Strengthening living instrument in this war is more important, the so-called morelweerbaarheid, they are the ones who must use the dead instrument" (Soetedjo, 1940: 246).

The statement was an allusion to the Dutch East Indies government intended to gain some advice from the National Fraction in 1937. At that time, National Fraction suggested that the government not hesitate to conduct militia (military service) for the Indonesians (Schrieke, 1937: 85).

To gain a great army and weaponry, Prof. Mr. J. J. Schrieke suggested that the government be able to see Japan. Schrieke (1937: 85) saw that the Japanese understood

“...that their country must be guarded with modern weaponry, to be able to afford army and navy, the way it should be in a modern country, Japan has started industrialization."

The statement was delivered because the government did not seem to want to build its domestic industry and thought to charge a high tax to Indonesians in order to earn money easily. The war cost imposed on Indonesian taxes can be seen in Mohammad Husni Thamrin's statement in a Volksraad session where he said that

"Spending for war supplies must be paid on borrowed money so there is no need to raise tax levy that undermines the spending power (consumptieve kracht) of the Indonesians" (Handelingen, 1940: 782).

Therefore, National Fraction would extend its support on the policy of war budget draft, otherwise it did not charge a high tax to. National Fraction also demanded that the military service that would be conducted should be followed by an extension of political and economic rights (Thamrin 1940: 201).

The National Fraction's suggestions were accepted neither by Volksraad nor by the Governor-General. National Fraction then proposed a motion related to the nomenclature of Indonesia in Volksraad. The motion was filed by Mohammad Husni Thamrin on 13 August 1940. For the political wing National Fraction, Indonesia's nomenclature was something that had to be fought for, in order to raise the degree of the Indonesians. This referred to article 55 of the Dutch East Indies Act, that is "Inheemsche onderdanen-niet Nederlanders" and 'inlander' nomenclature that contained an insult (Wignjowidjojo, 1940: 257-258). The motion was opposed by some European Volksraad members. They thought that such motion was a part of movevent to be independent from the Dutch (Wignjowidjojo, 1940: 259).

A few days after the motion was filed, Wiwoho also filed another motion related to the drafting of the IndiesNederland state order on 19 August 1940. Those motions were considered very sensitive so as to be discussed after the Dutch managed to escape from the Germany. In fact, the Dutch had been ruled by Germany since July 1940 and its government fled to Britain. The session that took place at that time had a very high emotional level because European representatives said that

"Political intelligence must be in harmony with social and economic intelligence; it is not good to entrust something in the hands of someone that is not yet competent for it" (Tjokrosoejoso, 1940: 280).

The allusion then led to a proposal to establish a commission to investigate the will of the people. National Fraction was offended by the establishment of the commission because it means that they did not trust Indonesian representatives. It can be seen from Mochtar's statement as follows

"Establishing a commissie in the interest to change the state administration is, I think, of no use, it is enough to just conduct discussion with the leaders of political movement to know the will of the people..." (Tjokrosoejoso, 1940: 282).

Nevertheless, Mochtar's statement was ignored when the government decided to form a Visman commission. 
The commission was etsblished on 25 September 1940 and led by Edeleer. Dr. F. H. Visman. The Commission had the following tasks:

"To investigate (find out) whether the interest is of certain groups or of the whole society in Indonesia about the change of state structure as well as among the government bodies..." (Thamrin, 1940: 125).

The commission only functioned to investigate yet had no right tochange, design or replace. In fact, the SOP of the commission was also questioned and criticized by the leader of National Fraction. He delivered a question and a statement at the same time as follows

"Whom does the Commission hear from? Of course, it is those who are aware of politics (Politiek Bewust). They, either some of them or all of them, have already become members of a political party" (Thamrin, 1940: 126).

Therefore, it was really unnecessary for the government to establish the commission since it was enough for them to simply ask the opinions of the representatives from all layers of society who sat in Volksraad.

The National Fraction thought that the government never took into account their opinions. Eventually in the late 1940, Mohammad Husni Thamrin stated an assertion to the government by saying that

"I think, if we examine the basic characteristics of the government here, we could see that the state of this country is not a state of independent country, but this country has a colonial status, meaning that our country is colonized for the use and interest of other countries, colonizers" (Handelingen, 1940: 783).

Such assertion was inseparable from the attitude of the government who rejected the motions submitted bythe Indonesian representatives. The Indonesians were also bored of the promises given by the Dutch East Indies government. Mohammad Husni Thamrin mentioned an example that

"Even to change the name only, that is not meaningful, just to change the name, Indladsch and Indlander to become, Indonesisch and Indonesier, the Dutch must disappear first and become an independent land...." (Handelingen, 1940: 785).

On the other hand, National Fraction also felt happy because the suggestion regarding military service was accepted by the government. However, National Fraction demanded that the military service be accompanied by an extension of political and economic rights.

National Fraction also expressed that they were offended because the Indonesians were considered immature in politics. Although the Indonesians were seen as stupid by the Westerners, they actually also thought about what happened in their homeland. Mohammad Husni Thamrin pointed it out by giving a statement as follows

"Among our people, we have Volkshumor (people's joke), they have once interpreted the word "Djintan" as "Djendral Japan Ini Nanti Toeloeng Anak Negeri" (This Japanese general later helps native people) (Thamrin 1940: 203).

The statement of the National Fraction leader, who came from Parindra, had made the Dutch East Indies government feel suspicious of the presence of traitors who sided with the Japanese government. The government's suspicion was inseparable from Mohammad Husni Thamrin's statement in 1934, the attitude of Parindra that sided with Japan (Thamrin 1937: 58), and the communication made by Mohammad Husni Thamrin with the Japanese leader by mail. The government then conducted a search to his house and the job was carried out by PID who later found a number of personal letters between Mohammad Husni Thamrin and Douwes Dekker and some reports of the Dutch East Indies economy to Sato (Hering, 2003: 390). The contents of the personal letter stated the attitude of Mohammad Husni Thamrin and National Fraction that oppossed the attitude of the government.

During the search, Mohammad Husni Thamrin was actually in a severe pain. However, the PID who found the evidence then isolated Mohammad Husni Thamrin's house which then led to his death due to a high fever on 11 January 1941. After National Fraction lost its leader, it then united with Indonesia's National Party on 15 July 1941 which then formed the Indonesian National Fraction.

The goal of the Indonesian National Fraction was the same as that of the National Fraction, that is to achieve Indonesia Merdeka. However, the struggle by this fractiondid not last long because the Dutch East Indies had fallen into the hands of the new ruler, namely Japan.

\section{CONCLUSION}

The establishment of the Volksraad generated two 
viewpoints, Indonesia and the Dutch. On the basis of the Dutch's viewpoints, Volksraad initially began with a proposal proposed by the Governor General Van Twist who wished local Council be established and ended up with the decision of 16 December 1916 through the approval-based Th. B. Pleyte's proposal to establish a Volksraad aligned with the Indies Council. Whereas from the Indonesian's standpoint, the establishment of the Volksraad initially triggered by the presence of the issue militia Bumiputera who later responded by Sarekat Islam and Boedi Oetomo so that first established representative body in the Dutch East Indies.

Radicale Concentratie and National Fraction are the peak of the struggle of Indonesia when noncooperative attitude is limited. Cooperative struggle is not a form of surrender of Indonesia to the colonists. Instead, it is a new way to gain independence.

The fact that Radicale Concentratie and National Fraction often failed due to applying voting system in the decision making process does not make the members give up. People's suffering seen by Indonesian representatives in Volksraad is the spirit to achieve independence. Therefore, the perspective of people's economy is the main weapon of Radicale Concentratie and National Fraction in fighting for the interests of Indonesia.

Indonesian struggle in the Dutch Indies Parliament ended after the government's power collapsed. Volksraad was later disbanded by the new Indonesian ruler, Japan.

\section{REFERENCES}

A. M. (1938). Petitie Soetardjo. Berita Kaoem Betawi, 9, 5. Adiputri, R. (2014). The Dutch Legacy in the Indonesian Parliament. Political Sciences and Public Affairs, 2(2).

Angelino, De Kat (1931). Colonial Policy. Nederland: Martinus Nijhoff.

Budiawan (2006). Anak Bangsawan Bertukar Jalan. Yogyakarta: LKiS.

Depdikbud (1978). Sejarah Kebangkitan Nasional Daerah Provinsi Jawa Timur. Jakarta: Balai Pustaka.

Foray, L. Jennifer (2013). A Unified Empire of Equal Parts: The Dutch Commonwealth Schemes of the 1920s-40s. The Journal of Imperial and Commonwealth History, 1-26.

Furnivall, J. S. (2009). Hindia Belanda: Studi Tentang Ekonomi Majemuk. Jakarta: Freedom Institute.

Handelingen van den Volksraad (1930). 59ste Vergadering Zaterdag 8 Februari 1930. Aanvulling Strafwetboek Met Bepalingen Tot Bestrijding van Revolutionnaire Woelingen. Motie-Thamrin cs. Batavia: Volksraad. pp. 1994.

Handelingen van den Volksraad (1933). 27ste Vergadering
Dinsdag 20 April 1933. Voorstel Thamrin Tot Het Houden van een Interpellatie Over Het Optreden van de Politie (Ond. 147). Batavia: Volksraad. pp. 346-347.

Handelingen van den Volksraad (1938). 22ste Vergadering Dinsdag 2 Augustus 1938. Begrooting van Nederlandsch-Indie vour 1939 (Ond.1), Algemeen Gedeelte. Batavia: Volksraad.pp. 637.

Handelingen van den Volksraad (1940). 50ste Vergadering Zaterdag 9 November 1940. Begrooting van Nederlandsch-Indie voor 1941 (Ond.1), Algemeen Gedeelte. Batavia: Volksraad.1940. pp. 782-785.

Hatta, Mohammad (2011). Untuk Negeriku: Berjuang dan Dibuang. Jakarta: Kompas.

Hatta, Mohammad (1934). Krisis Ekonomi dan Kapitalisme. Batavia: Soetan Lembaq Toeah \& Fa.

Hatta, Mohammad (2015). Politik, Kebangsaan, Ekonomi (1926-1977). Jakarta: Kompas.

Helsdingen, W. H. van (1928). Pekerdjaan Dewan Ra'jat Sepoeloeh Tahoen. Batavia: Balai Poestaka.

Hering, Bob (2003). M. H. Thamrin: Membangun Nasionalisme Indonesia. Jakarta: Hasta Mitra.

Houben, Vincent (2013). The Indonesian Eurasian Community and Japan. Internationales Asienforum, 44(3-4), 227-237.

Keizer, Munick (1939). Dari Indonesia Merdeka ke Indonesia Berparlemen. Keboedajaan dan Masjarakat, 306308.

McVey, T. Ruth (2009). Kemunculan Komunisme Indonesia. Jakarta: Ombak.

Paulus, B. P. (1979). Garis Besar Hukum Tata Negara Hindia Belanda. Bandung: Offset Alumni.

Poerbopranoto, R Koentjoro (1938). Dewan Ra'jat (Volksraad). Batavia: Balai Poestaka.

Pringgodigdo, A. K. (1986). Sejarah Pergerakan Rakyat Indonesia. Jakarta: Dian Rakyat.

Ricklef, M. C. (2011). Sejarah Indonesia Modern. Yogyakarta: UGM Press.

Riphagen, J. (1927). Atoeran Pemerintahan Hindia Belanda. Weltevreden: Balai Poestaka.

Salim, Agus (1936). Hindia Berdiri Sendiri: Usul Petisi Soetardjo cs dan Para Pembitjaraan dalam Volksraad. Batavia: Firma. H. F. Boersma.

Schrieke, J. J. (1937). Soal Militie. Soeara Parindra, September Tahun Ke II, 84-85.

Shiraishi, Takashi (1997). Zaman Bergerak: Radikalisme Rakyat di Jawa, 1912-1926. Jakarta: Midas Surya Grafindo.

Simbolon, T. Parakitri (2007). Menjadi Indonesia. Jakarta: Kompas.

Soedirman (1940). Rentjana Perkoeatan Armada Laoet. Soeara Parindra, April Tahun Ke V, 140-155.

Soekarno (1963). Di Bawah Bendera Revolusi Jilid I. Djakarta: Panitia Penerbit. 
Soerjohardjo, Wardiningsih (1976). Volksraad dan Konsentrasi Radikal. Unpublished Undergraduate thesis, Faculty of Cultural Sciences Department of History, University of Indonesia, Indonesia.

Soetedjo (1940). Meneropong Volksraad. Soeara Parindra, November Tahun Ke V, 245-253.

Soetomo, R. (1937). Teropong. Soeara Parindra, Agustus Tahun Ke II, 50-52.

Suhatno, dkk. (1995). Tokoh-Tokoh Pemikir Paham Kebangsaan. Jakarta: Departemen Pendidikan dan Kebudayaan.

Tempo (2013). Agus Salim: Diplomat Jenaka Penopang Republik. Jakarta: Kepustakaan Populer Gramedia.

Thamrin, M. H. (1934). Algemeene Beschouwingen in den Volksraad op 13 Juli 1934. Batavia: Volksraad.

Thamrin, M. H. (1937). Dalam Volksraad. Soeara Parindra, Agustus Tahun Ke V, 57-59.

Thamrin, M. H. (1940). Komisi Visman: Oentoek Mengetjat Roemah Dipakai Toekang Besi! Soeara Parindra, November Tahun Ke V, 125-132.
Thamrin, M. H. (1940). Pemandangan Oemoem dalam Volksraad. Soeara Parindra, Desember Tahun Ke V, 194-203.

Tjokrosoejoso, Abikoensio (1940). Kepentingan Tata-Negara dalam Volksraad. Soeara Parindra, November Tahun Ke V, 278-287.

Wanhar, Wenri (2014). Jejak Intel Jepang: Kisah Pembelotan Tomegoro Yoshizumi. Jakarta: Kompas.

Wignjosoebroto, Soetandyo (2014). Dari Hukum Kolonial ke Hukum Nasional: Dinamika Sosial-Politik dalam Perkembangan Hukum di Indonesia. Jakarta: Epistema Institut.

Wignjowidjojo (1940). Seboetan Indonesia dalam Volksraad. Soeara Parindra, April Tahun Ke V, 256-259.

Wongsokoesoemo, Roeslan (1940). Perobahan Volksraad dan Raad van Indie. Soeara Parindra, November Tahun Ke V, 267-269. 